\title{
How student characteristics affect cooperative students' digital competences: A latent profile study
}

\author{
Lydia Schulze Heuling ${ }^{1} \&$ Steffen Wild ${ }^{2}$
}

${ }^{1}$ Western Norway University of Applied Science, Norway (lshe@hvl.no)

${ }^{2}$ Heidelberg School of Education, Heidelberg University, Germany

\begin{abstract}
The use of information and communication technologies (ICT) profoundly impacts industry and work. It therefore is important for vocational education and training to emphasize on the development of digital competences. However, we still know very little about how these skills are distributed among students in vocational education and training (VET) in general, and the so-called 'cooperative study programmes' (CSP) in particular. CSPs combine vocational education components with university coursework leading up to a journeymen certificate and an academic degree simultaneously. This study analyses the digital competences of first-year students in a business-focussed CSP at the Baden-Wuerttemberg Cooperative State University (DHBW) in Germany, using a German version (the D21-Index) of the European framework for digital competences (DigComp) to assess students' competence levels. A latent profile analysis revealed four competence profiles (reserved digitised, reserved appreciative, constructive digitised, and reflective digitised). Interestingly, our subsequent analysis showed that none of the student characteristics we assessed turned out to be distinctive for any of the four profiles. Considerations of relevant inset points for VET institutions nationally and internationally to develop tailored support of digital competence development of their students are integrated in the conclusions.
\end{abstract}

Keywords: digital competences, DigComp, co-op students, latent profile analysis, business school 


\section{Introduction}

With the growing ubiquity of digitalisation and Information and Communication Technologies (ICT) in everyday life, ICT-competences have become a basic requirement to actively participate in society (Balsmeier \& Woerter, 2019; Brynjolfsson \& McAfee, 2017; Kurz \& Rieger, 2013). Furthermore, technological advancements and the increased availability of ICT resources have changed traditional learning and working environments and will continue to do so in the future (Siddiq \& Scherer, 2019; Skryabin et al., 2015; Hu et al., 2018). Impacting on many occupational fields and professions, digital skills and competencies are expected to be one of the major driving forces for innovation and competitiveness. For this reason, digital knowledge is now in demand for almost every apprenticeship area.

In vocational education and training (VET) contexts, digital media typically presents a strong fusion of methodological and content-related knowledge. This is particularly true when digital media are present as a blend of the apprentice's working environment and that of her or his vocational school. For example, working with an established company software for accounting in commercial VET or programming logic controllers (SPS) is a non-resolvable amalgamation of simultaneously learning for and with digital media. Against this background, learning venues must be outfitted with the latest technological developments and, ideally, will change dynamically in response to shifting processes. This applies both to the latest technology and the corresponding learning scenarios.

The following sections offer a brief overview of the German vocational and cooperative educational system, before moving on to take a closer look at current research findings on digital competences in VET and CSP.

\section{The vocational and cooperative educational system in Germany}

Traditionally in Germany, after completing their compulsory education, school students must decide whether to continue on to general upper secondary school (Gymnasium) leading to the university entrance qualification 'Abitur,' or opt for a vocational apprenticeship leading to a journeyman certificate. Vocational apprenticeship combines specific on-the-job training in a partner company with a general vocational education in a vocational school (representing $3 / 5$ and 2/5 of the student's apprenticeship time, respectively). An apprenticeship traditionally lasts three years. Graduates from an apprenticeship typically hold a journeymen certificate and generally have good perspectives in the labour market.

Despite these advantages, vocational education in Germany currently faces major challenges. Interest in vocational education in Germany has decreased over the past 20 years (Baas \& Baethge, 2017), such that, in 2016 alone, there was a $25 \%$ rescission of apprenticeship contracts (Federal Institute for Vocational 
Education and Training, 2018; Federal Ministry of Education and Research, 2018). One explanatory factor behind this waning interest in VET programmes may be the growing lack of connection between vocational school and practical on-thejob training components of such programmes. In many cases, communication between school and company is infrequent and/or unsatisfying for partner companies. In this context, skills and professional knowledge are coordinated and transmitted in a less than optimal way - a particularly frustrating experience for both the apprentice and the company responsible for providing training (Schulze Heuling, 2017). Another reason may be the scarcity of candidates for apprenticeship posts, as many of the companies willing to train new apprentices cannot find eligible candidates for their open positions. Yet another factor may be the fact that structural changes in the economy towards service-orientated professions has changed the set of skills that are now required of new employees. At the same time, some service sectors have witnessed an increasing rise in the numbers of people working without professional training (Seeber \& Seifried, 2019). Keeping in mind that training is increasingly geared towards the so-called 'Fourth Industrial Revolution' (Industry 4.0) and advanced ICT skills, it is noteworthy that many vocational schools in Germany often have antiquated teaching equipment. This was also found to be the case for IT-related apprenticeships, such as IT-supporter (Schulze Heuling, 2018). In such a situation it is very demanding for VET teachers to offer up-to-date education that relates to the latest changes in job-related ICT developments.

\section{Cooperative study programmes in Germany}

In Sweden, all VET programmes in upper secondary school have the opportunity of basic eligibility to higher education. And earlier (1994-2011), courses that gave basic eligibility for higher education were compulsory in Swedish VET programme in upper secondary school. Norway and Denmark offer joint programmes in which students can simultaneously earn their baccalaureate and a journeyman certificate. The Yrkes- og studiekompetanse programme (YSK) in Norway leads to 'both a craft- or journeyman certificate and a general education qualification at EQF level 4 after completion' (Haukås \& Skjervheim, 2018, p. 22). Students within the YSK receive a salary from the industrial partner right from the beginning (a salary for the training times in enterprise is given from day one, after two years they are legally apprentices with salary accordingly) (Haukås \& Skjervheim, 2018, pp. 22-23). The eux programme, erhvervsuddannelse og gymnasial eksamen, in Denmark combines a general upper secondary education with a vocational education and training. It lasts between three and four years, depending on previous experience of the candidate (Undervisningsministeriet, 2019).

Germany's comparable joint programme - cooperative education - is offered at a later educational stage. The German cooperative education model combines a vocational education programme leading to the journeyman certificate with a 
bachelor-level university degree programme (Graf et al., 2014). With this type of education, companies and universities of applied sciences develop special learning environments for their students, with the university delivering the more general and theoretical input and the partner company providing the practical dimensions of the student's chosen profession (Reinhard \& Pogrzeba, 2016).

Cooperative education is relatively uncommon and varies internationally, for example in terms of its format and scope. Studies from Coll and Zegwaard (2011), Graf (2013), and Reinhard, Pogrzeba et al. (2016) found that a common characteristic shared by all CSPs is that they require a minimum level of student work experience in the partner company. They further find an apparent international consensus among CSPs to avoid changing or reforming the CSP curricula too quickly such that short-term trends can be distinguished from long-term developments. In this way, the institutions involved expect to ensure that their benefits are not restricted to the short term.

The Baden-Wuerttemberg Cooperative State University (DHBW) is one of the largest institutions for cooperative education in Germany, offering CSPs in small cohorts of up to 30 students. Currently, it offers nearly 34,000 enrolled students bachelor's degree programme options in three majors: business administration, engineering and social work. Figure 1 shows the two main routes for enrolling at the DHBW, based on the prerequisites of the German tertiary education system. The first and most common route is for students to take the general university entrance examination (Abitur) and then go on to start their cooperative stud. The second route, for those students who possess only the lower Abitur or 'Fachhochschulreife,' is to take an entrance examination (Deltaprüfung) before starting cooperative study.

The DHBW degree programmes award students a total of 210 European Credit Transfer System (ECTS) points distributed over six semesters. By comparison, the average number of ECTS for a bachelor's degree at a German university is 180 . Additionally, DHBW apprentices spend half of their time at the university and half of their time with the partner company, shifting venues every three months. In contrast to a typical CSP (Figure 2), the DHBW does not provide students with a company training position; rather, it requires them to show proof of an apprenticeship contract with a company that is willing to train them as an institutional partner in accordance with the CSP requirements, as a prerequisite for enrolling in one of its CSPs. 


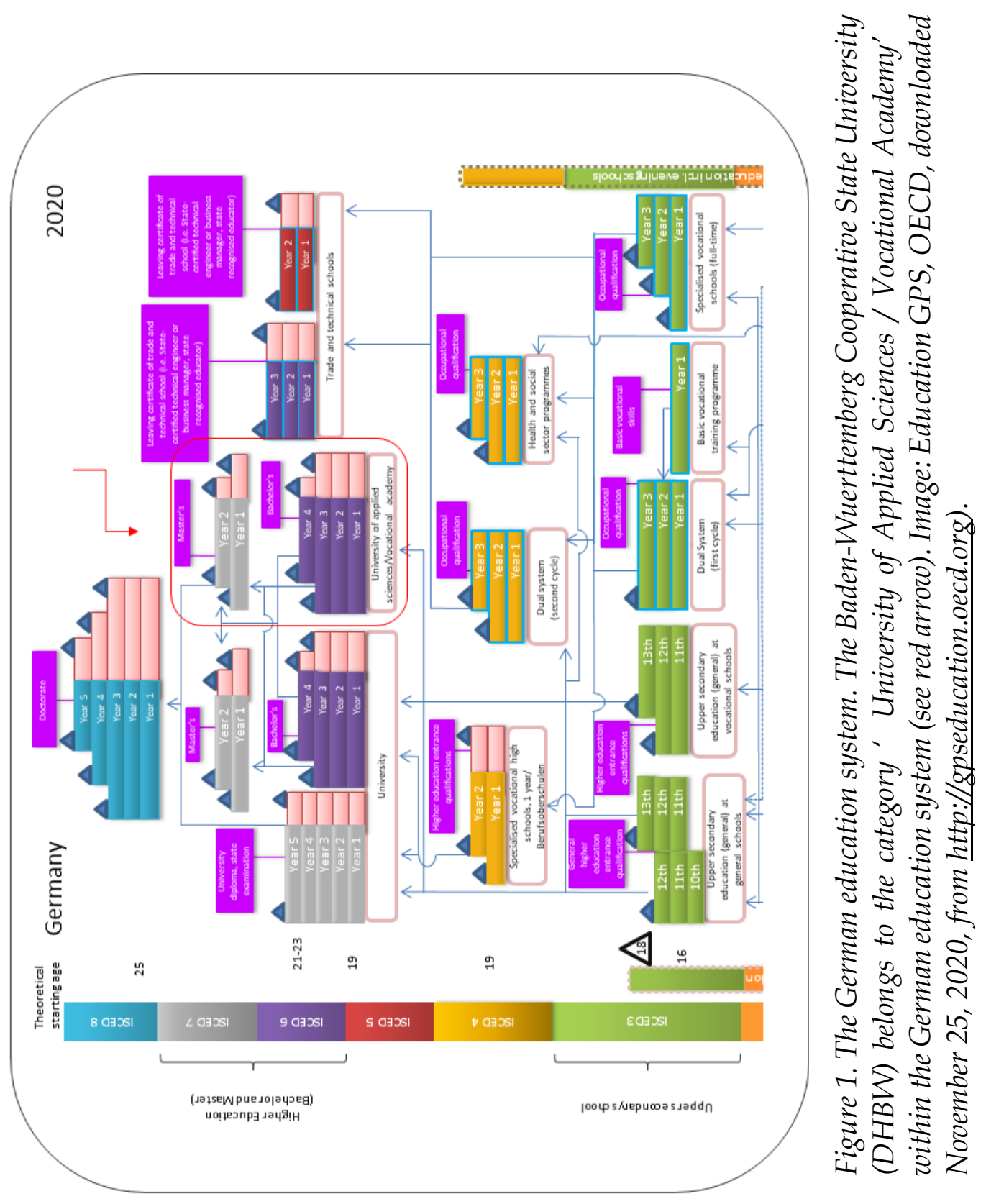


In contrast to apprenticeships, the number of students in CSPs in Germany is increasing (Wolter, 2016). In 2019, a record 108,202 students enrolled in CSPs, compared to 64,358 in 2013 (Hofmann et al., 2019). There are many reasons why students opt for a CSP after completing their secondary school studies. One benefit, for example, is that students in CSPs receive a monthly salary for the entire duration of their bachelor's degree studies. The company must pay this salary even during the academic training phases. Since they have the status of regular apprentices, they also benefit from vacation entitlement and insurance protection. After graduating from such a programme, these students expect higher salaries and access to positions with better career options than graduates from other higher educational programmes.

And the figures do them right. Research on graduates of the DHBW show that they enjoy higher employability and job security rates than students from other universities. Nearly $83 \%$ of the students graduating from a CSP are offered a permanent position by their corporate partner (Statistisches Landesamt BadenWürttemberg, 2016). In return, the companies also reap many benefits from CSPs. For example, CSP students carry out company tasks as part of the practical work required for the academic degree. By the time they graduate, these students are already skilled workers who have been specifically trained to meet the needs of their companies. For the corporate partner companies, this setup means lower staff turnover and reduced recruitment costs. In essence, CSP graduates require only a very short period of vocational adjustment in order to become productive employees (Braunstein et al., 2011; Reinhard \& Pogrzeba, 2016). Overall, CSPs have a high reputation in Germany and their popularity is increasing (Kramer et al., 2011).

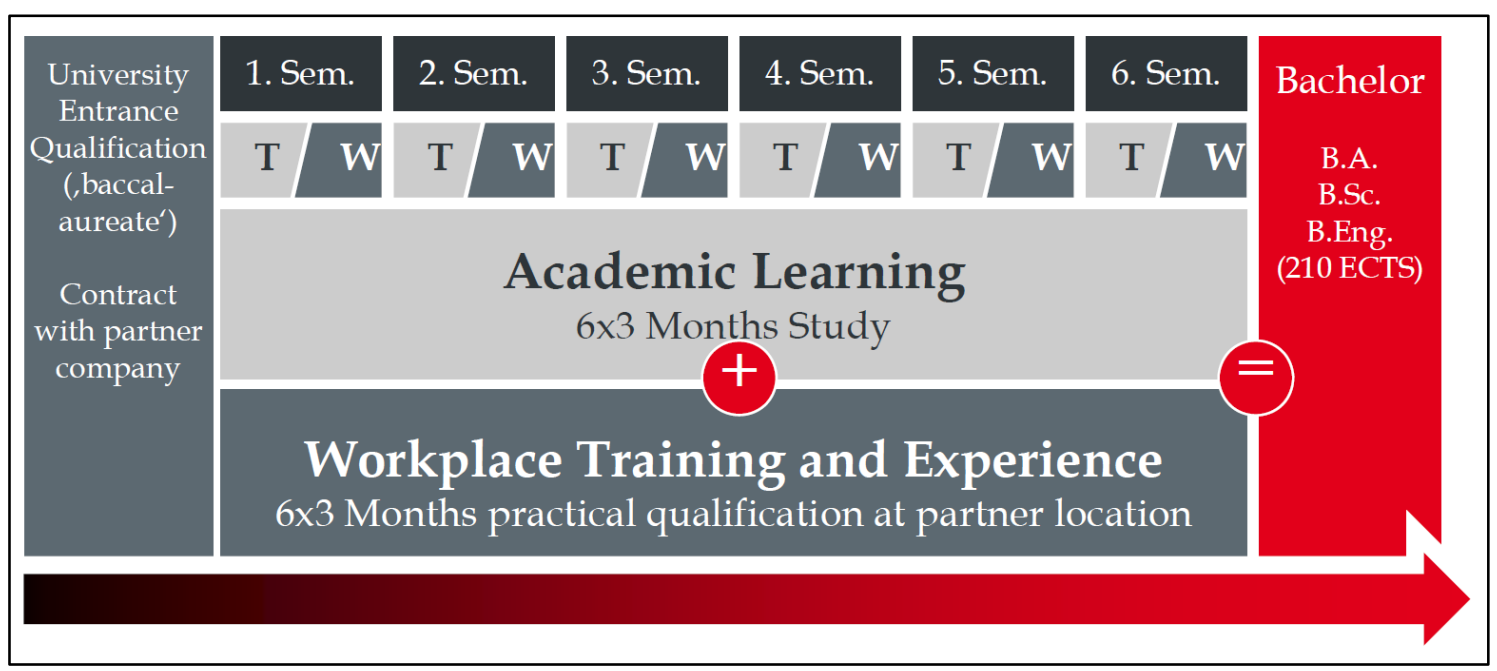

Figure 2. Study model of the Baden-Wuerttemberg Cooperative State University (cf. Wild $\mathcal{E}$ Neef, 2019). 
What we know about student characteristics in CSPs

Despite their attractiveness and obvious advantages, CSPs also carry a heavy and demanding workload. Nevertheless, the commitment to the partner company and the students' personality seem to be influencing factors to prevent high dropout rates (Wild \& Schulze Heuling, 2020a). Which brings us to the question: what kind of people opt to enrol in a CSP? In a recent panel study, we surveyed the BIG-5 personality traits of several hundred students enrolled in a CSP and found highest scores for the characteristics 'openness' and 'extraversion' (Wild \& Schulze Heuling, 2020a). Kramer et al. (2011) found that cooperative education students tend to have a lower socio-economic background than other university students. At the same time, students in cooperative education programmes have higher cognitive abilities (as shown by assessment tests) and higher university entrance scores than do students from other higher education institutions. Researchers also found that cooperative education students tend to prefer the practical element of their studies, taking on the academic portion of the programmes mainly in order to improve their future salary and career options (Kramer et al., 2011; Weich et al., 2017). Furthermore, Weich et al. (2017) report a higher level of self-confidence among cooperative education students, and Kupfer (2013) notes that, in comparison to other students, cooperative students are more convinced of their independence and their motivation to study.

\section{Students' digital competences: Findings in the literature}

Most research on digital competences focuses on primary and secondary education. Siddiq et al. (2016) show this in their review of assessment instruments in this area. However, there is a small corpus of related research on VET and CSPs.

\section{General findings}

Smith et al. (2013) summarize that in most countries upper secondary school students lack the information literacy proficiency required to succeed in the postsecondary educational environment. Specifically, for Germany, Senkbeil et al. (2019) in their recent study use data derived from the German National Educational Panel Study (NEPS) and show that a high proportion of first-year students $(20 \%)$ and sixth-semester students (52\%) do not meet the foundation level requirement. The both groups show differences in their ICT-related competencies, depending on their areas of study and gender.

There are some empirical results for secondary school education in the Nordic countries. In a multilevel analysis with Norwegian seventh grade students, for example, Hatlevik et al. (2015) found that mastery orientation and self-efficacy (motivation) and the student's family background (language integration and the number of books at home) were predictors of students' digital competence levels. 
Kaarakainen et al. (2017) found a gender effect among students in Finland's ninth grade. In their study, boys tended to get better scores on more technically oriented items, whereas girls received better scores on items related to schoolwork and social interaction. Regarding research on teachers in Norway, Hatlevik and Hatlevik (2018) show that teacher self-efficacy and collegial collaboration had a positive effect on the use of ICT in their teaching practice.

\section{Digital competences in VET and cooperative education}

Comparisons of ICT usage in European schools reveal certain differences by country. For example, laptop use in Sweden in educational settings has been shown to be higher than the European average. Furthermore, in Swedish vocational education the provision and use of both school desktop or laptop computers and the use of ICT instructional equipment exceeds not only the European average, but also that of Swedish schools in general (Survey of Schools: ICT in Education, 2012). In an earlier comparative study of European countries, Mc Cullough et al. (2002) found that Finland and Sweden have the highest classroom instruction time in VET spent with ICT (67\% and 76\%, respectively). Concerning the comparative digital competences of VET students versus CSP students, Wild and Schulze Heuling (2020b) found that students in VET tend to have lower digital competences than CSP students. Nevertheless, they found no solid demographic predictors in their data influencing the development of digital competences.

Furthermore, VET researchers (de Witt, 2012) point out that digital media competencies relevant to certain professions are still primarily acquired by the apprentices informally. Thus, they conclude, it is all the more important for foundational ICT competences in VET to target the appropriate learning context and that they be embedded in innovation strategies. Burchert and Schulte (2014) present an overview on how the internet can support VET education, but their focus does not allow them to address some key issues, such as the existence of special learning apps for VET. All in all, there is a need for further research and innovation in VET, ICT usage, and digital skills. Professional and personal competence of those involved remains decisive for the sensible use of digital media and promoting digital competences in VET.

In a recent literature review Kämäräinen et al. (2019, p. 193) emphasised that both students and teachers in VET need better digital competences, concluding that further steps are required to promote digital literacy in VET education. These are: i) shaping outreach activities to promote innovations (in using digital tools) to wider education and training contexts, ii) reflecting on challenges posed by the learning behaviour of older and younger learners vis-à-vis the introduction of digital tools, and iii) using generic and overarching frameworks and/ or contextspecific training models to shape CPD initiatives. In addition to the prerequisites of the teachers, training site, and vocational school, however, there are other 
factors influencing the formation of digital competences. One related theory concerns the so-called 'digital divide.'

\section{The digital divide}

The term digital divide is tied with the concept of social inequalities (Ragnedda \& Muschert, 2018). The core findings are differences in access to and use of ICTs depending on population segment characteristics and country (Castells, 2001; DiMaggio et al., 2001; Rowsell et al., 2017; Witte \& Mannon, 2010).

Most studies reveal a gender gap with respect to digital competences and show a correlation between socioeconomic status (SES) and ICT literacy among all levels of education. For example, Scherer and Siddiq (2019) show in a metaanalysis that girls perform better than boys on performance-based ICT literacy assessments $(g=.12)$. But most studies show that men outperform women in terms of access to digital resources and general digital competences (Cooper, 2006; Davaki, 2018). Focusing on SES, Scherer and Siddiq (2019) conducted a meta-analysis among K-12 students. They found a correlation between SES and ICT literacy with $r=0.21$.

Research also points out that the patterns of digital divide transgress into VET and higher education (Murray \& Pérez, 2014; Wild \& Schulze Heuling, 2020b). Therefore, we will also pay attention towards the question if the skills gap among students related to SES and gender reproduces in this study. If so, this would require attention from teacher educators and higher education institutions (Goldhammer et al., 2016; Kaarakainen et al., 2017). It is, therefore, important to understand the interrelationships between ICT use, learning and development, and learning conditions (Canchu \& Louisa, 2009; Tadesse et al., 2018).

\section{The digital competence framework of this study}

To assess students' digital competences, this study draws on a German version (D21-Index, Figure 3) of European digital competence framework DigComp (Ferrari, 2013). The DigComp framework has five competence dimensions: (1) information and data literacy, (2) communication and collaboration, (3) digital content creation, (4) safety and (5) problem solving (Table 1).

Information and data literacy are defined as the ability to identify, locate, retrieve, store, organise and analyse digital information. An advantage of this competence is that it allows an individual to judge the relevance and purpose of information and data.

Communication and collaboration are based on sharing resources through online tools and collaborating through digital tools with other people in the digital environment. An interaction with and participation in communities and networks exists, as well as the need for cross-cultural awareness. 
Digital content-creation is the creation and editing of new content (from word processing to images and video). This ability focuses on creative expression, media output and programming. Dealing with and applying intellectual property rights, as with licenses, is also an important aspect.

The dimension safety is of great importance, due to the need for personal protection, data protection, digital identity protection, security measures, safe and sustainable use of digital technologies.

Problem solving involves the skill of identifying digital needs and resources. Informed decisions on the most appropriate digital tools should be made in accordance with the proposed purpose or need. Conceptual and technical problems can be solved through digital means. A creative use of technologies and updating one's own and other's competences are important skills in this dimension.

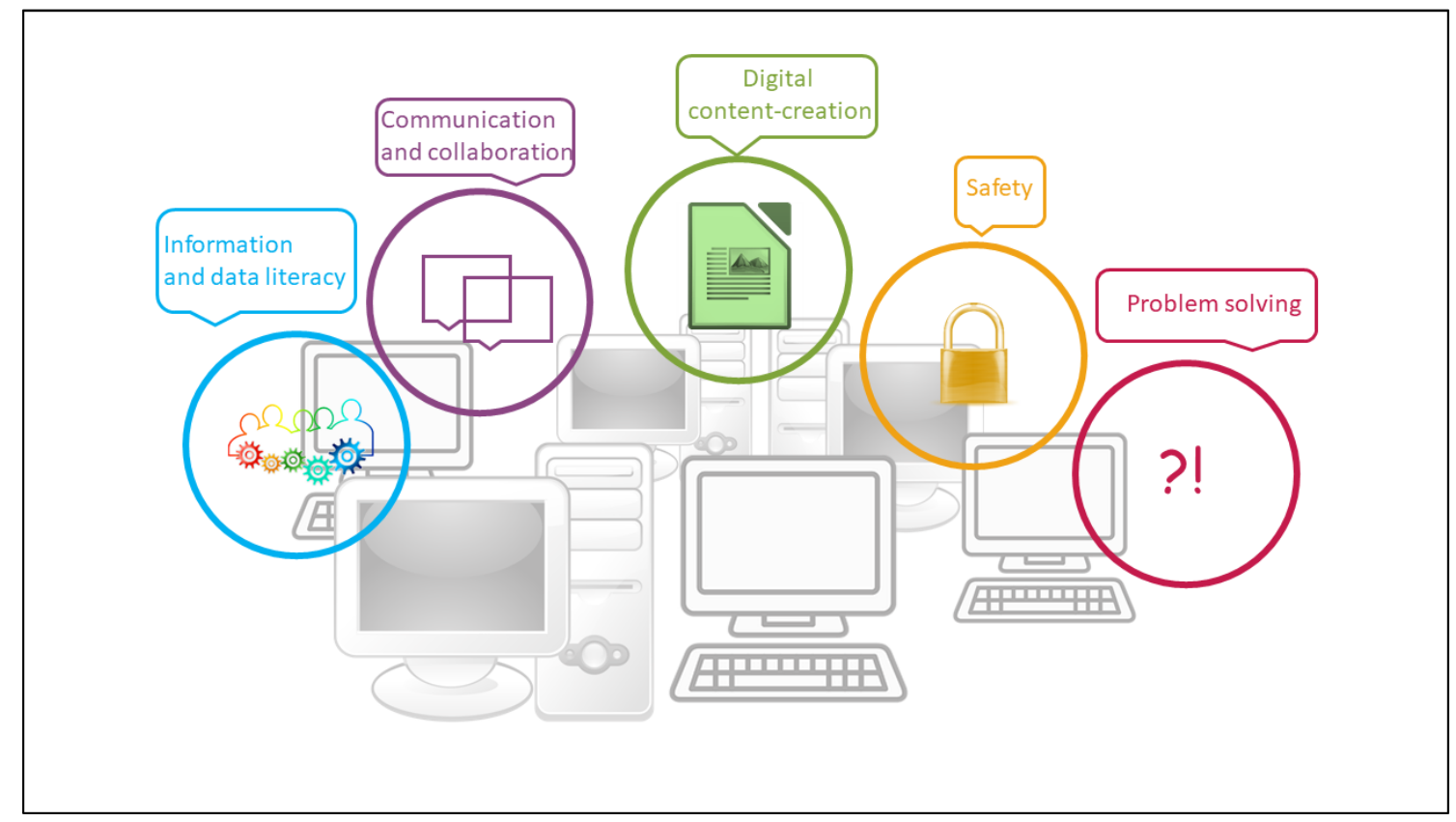

Figure 3. Overview of the five competences according to the European framework of digital competences DigComp.

\section{Aims of the current study}

Analysing data from first-year students is especially important, as this knowledge can be used to adjust the curricula for the subsequent study years. With this in mind, we sought to identify the digital competence levels of first year CSP business students. Furthermore, we explored whether the effects of the digital divide applied to our sample. 
Lydia Schulze Heuling \& Steffen Wild

Table 1. A summary of the DigComp competences and the description, according to Ferrari (2013).

\begin{tabular}{ll}
\hline Dimensions of competence & Description \\
\hline Information and data literacy & $\begin{array}{l}\text { Locate, retrieve, identify, store, organise and analyse } \\
\text { digital information, judging its relevance and purpose. }\end{array}$ \\
Communication and collaboration & $\begin{array}{l}\text { Communicate in digital environments, share resources } \\
\text { through online tools, link with others and collaborate } \\
\text { through digital tools, interact with and participate in } \\
\text { communities and networks, cross-cultural awareness. }\end{array}$ \\
Digital content-creation & $\begin{array}{l}\text { Create and edit new content (from word processing to } \\
\text { images and video); integrate and re-elaborate previous } \\
\text { knowledge and content; produce creative expressions, } \\
\text { media outputs and programming; deal with and apply } \\
\text { intellectual property rights and licences. }\end{array}$ \\
Pafety & $\begin{array}{l}\text { Personal protection, data protection, digital identity } \\
\text { protection, security measures, safe and sustainable use }\end{array}$ \\
Problem solving & $\begin{array}{l}\text { Identify digital needs and resources, make informed } \\
\text { decisions on most appropriate digital tools according } \\
\text { to the purpose or need, solve conceptual problems } \\
\text { through digital means, creatively use technologies, } \\
\text { solve technical problems, update own and other's com- } \\
\text { petence. }\end{array}$ \\
\end{tabular}

\section{Method}

Design

We collected data from a survey with 413 participants in a cross-sectional design. The sample participants were selected from a cluster sample. This was obtained by asking the person responsible for the courses industry trading and industrial management in the bachelor programme of DHBW in the outposts Karlsruhe, Loerrach and Ravensburg to distribute questionnaires to their complete cohort of freshmen. Questionnaires were returned to the head of the research project. An exact response rate cannot be given, due to this procedure, because we do not know how many students in total were actually present in each class.

The survey was completed during the lecture period, from November 2018 to March 2019, using a paper and pen questionnaire. A privacy policy was adhered to and participation was voluntary. No incentives were given.

In the sample, $59.7 \%$ of the participants were female students, $39.6 \%$ were male, and $0.7 \%$ could not be assigned as male or female (diverse). The mean of 
How student characteristics affect cooperative students' digital competences

age of sample participants was $M=20.45(S D=1.87) .95 .9 \%$ of the participants were in their first academic year.

Table 2. Student characteristics and mean values for $n=413$ participating students.

\begin{tabular}{|c|c|}
\hline Item & $\begin{array}{c}\text { Proportion / } \\
\text { Mean }(M) \text { with Standard deviation }(S D)\end{array}$ \\
\hline Age & $\begin{array}{l}M=20.45 \\
(S D=1.87)\end{array}$ \\
\hline Social Background* & $\begin{aligned} M & =6.35 \\
(S D & =1.58)\end{aligned}$ \\
\hline \multicolumn{2}{|l|}{ Vocational apprenticeship } \\
\hline Yes & $30 \%$ \\
\hline No & $70 \%$ \\
\hline \multicolumn{2}{|l|}{ University entrance qualification } \\
\hline Yes & $85 \%$ \\
\hline No & $15 \%$ \\
\hline \multicolumn{2}{|l|}{ Parents with an academic background } \\
\hline Yes & $48 \%$ \\
\hline No & $52 \%$ \\
\hline \multicolumn{2}{|l|}{ Year of graduation from school } \\
\hline 2016 or before & $38 \%$ \\
\hline 2017 & $17 \%$ \\
\hline 2018 & $45 \%$ \\
\hline \multicolumn{2}{|l|}{ Academic major } \\
\hline Industry Trading & $55 \%$ \\
\hline Industrial Management & $45 \%$ \\
\hline \multicolumn{2}{|l|}{ Sex } \\
\hline Male & $39 \%$ \\
\hline Female & $60 \%$ \\
\hline Could not assigned to a male or female & $1 \%$ \\
\hline
\end{tabular}

* Based on self-estimation ranging from 1 (= low) to 10 (= high).

\section{Participants and instrument}

Table 2 gives an overview of the student characteristics found in the sample. The participants had an average age of $M=20.45(S D=1.87)$. Social background was measured by a subjective self-report. For the question 'What social class did you belong to when you were 15 years old?' students could answer on a scale from 1 (= lowest) to 10 (= highest). The mean value of $M=6.35(S D=1.58)$ indicates that 
the majority of students considered themselves to be middle class. Of the sample, $30 \%$ already had a journeyman certificate from an apprenticeship, 15\% had entered the DHBW study programme without a general university entrance certificate, having taken an external examination for students with journeymen certificate and a minimum of five years' work experience. The other $85 \%$ had a university entrance qualification, $48 \%$ of whom had parents with an academic background (defined as having at least one parent with a university degree). The year of school graduation varied among the participants. The distribution shows that $38 \%$ had graduated in '2016 or before,' 17\% in the year 2017, and 45\% had graduated more recently, in 2018. Finally, demographic data showed that 55\% were pursuing the academic major 'Industry Trading' and the other 45\% were enrolled on the 'Industrial Management' programme.

To measure students' digital competences, our study used the tool from the German D21-index in the slightly modified version presented by Müller et al. (2018), based on the DigComp framework (Ferrari, 2013). The instrument validation delivered good results for reproducing the scales proposed by the original framework. A detailed analysis of the instrument is published here (Wild \& Schulze Heuling, 2021). Self-reports were used, allowing the respondents to quote an item in a bubble of the questionnaire with a single choice option, if the item was applicable. The decision to measure the items in this way, based on selfreports, was based on the argumentation that 'although errors surely do occur, they often do not severely limit the validity of the measures' (Lucas \& Baird, 2006, p. 41).

Measurement quality was analysed using the item response theory of an approach by Birnbaum (1968). The 24 items with five dimensions show an acceptable measurement quality and were introduced with the phrase 'What can you do, recognise and what is your behaviour' with reference to the following categories: information and data literacy (EAP/PV-Reliability $=.66 ; 5$ items; item example: data transmission between devices), communication and collaboration $(\mathrm{EAP} / \mathrm{PV}-$ Reliability $=.64 ; 4$; item example: recognising fake news): digital content-creation (EAP/PV-Reliability $=.69 ; 5$ items; item example: design web applications), safety (EAP/PV-Reliability $=.56 ; 5$ items; item example: regular updates of antivirus software), and problem solving (EAP/PV-Reliability $=.74 ; 5$ items; item example: establishment of a (home)network).

\section{Statistical analyses}

In the analysis, Latent Profile Analysis (LPA) with the software MPLUS (Version 7.11) was used to classify persons in heterogeneous subgroups. This type of analysis aims to characterise combinations of group-specific features (profiles), which are as homogeneous as possible within a group, and can be clearly differentiated between the groups (Bacher \& Vermunt, 2010). An LPA is a person-centred approach within item-response theory (Gollwitzer, 2012). The analysis uses 
continuous indicator variables, in contrast to latent class analysis (Muthén \& Muthén, 2010, p. 158). A person is assigned a profile in a probabilistic way, in accordance with the profile with which she/he fits the best. We chose LPA because it has advantages over a traditional cluster analysis, offering more flexible model specifications and statistical fit indexes as well as more accurate comparisons of models with different profiles (Pastor et al., 2007).

In order to select the optimal number of profiles, we formulated five different profile solutions. The selection was based on estimations from the Bayesian Information Criterion (BIC), the Sample Size Adjusted BIC (ssaBIC) and the Akaike Information Criterion (AIC). Lower values indicate a better model fit. In addition, the Bootstrap Likelihood Ratio Difference Test was employed. A significant hypothesis test indicates that an estimated model, with a certain number of profiles, maps the empirical data statistically better than a comparison model with one profile less. To evaluate the classification quality (Fit), the Entropy measure was used. Values of up to one for entropy mean a better solution (Geiser, 2010). For evaluating the analysed profiles, a discriminant analysis was used. The evaluation, using the SPSS software (Version 25), does not group the data, but tests how well the variables differ in the groups already identified (Tabachnick \& Fidell, 2013, p. 419ff.). In this analysis, the leave-one-out method was chosen as the cross-validation method in this procedure (Browne, 2000; Künsting et al., 2012). In this way, a strong sampling reduction is avoided, because there is no need to split the data into two subsamples. For the purposes of the analysis, one case was ignored for $\mathrm{N}$ runs $(\mathrm{K}=\mathrm{N})(\mathrm{N}-1)$, and the remaining cases were used to determine the discriminant functions, until all cases were eventually eliminated. According to this classification rule, the error probability of the group assignment of the respective excluded case is determined. Based on correctly classified cases, the quality of the data can be assessed. We used median $(M d)$ instead of mean $(M)$ calculations, because there exist outliers in data. For this reason, the correlation of Spearman $\left(r_{s}\right)$ instead of the correlation of Pearson $(r)$ is estimated.

\section{Results}

\section{Preliminary analyses and descriptive statistics}

In a first step we give an overview of the median $(M d)$, standard deviation $(S D)$, minimum (Min), maximum (Max) and correlations according to Spearman $\left(r_{s}\right)$ of the five dimensions of digital competences. The results are set out in Table 3 , below. The standardised thetas $(\theta)$ of the median of all five dimensions are distributed around the value 0 (from $M d=-.05$ to $M d=.11$ ). This is no surprise, because $\theta=0$ equates to the characteristic value of the weighted sum index of classical test theory. The standard deviation varies between $S D=.52$ (information and data literacy) and $S D=1.12$ (safety). Hence, one can summarise that the 
distribution of data in terms of the standard deviation is small but considered sufficient for further analysis. This can be concluded by the width in the data of the minimum and maximum of $\theta$ too. The correlations of the five dimensions vary between $r_{s}=.37$ and $r_{s}=.49$ and are moderate.

Table 3. Descriptive statistics $(\theta)$ and correlations according to Spearman $\left(r_{s}\right)$ from digital competences $(n=413)$.

\begin{tabular}{|c|c|c|c|c|c|c|}
\hline & & 1. & 2. & 3. & 4. & 5. \\
\hline \multicolumn{2}{|c|}{ Information and data literacy } & - & & & & \\
\hline \multirow{2}{*}{\multicolumn{2}{|c|}{$\begin{array}{l}\text { Communication and } \\
\text { collaboration }\end{array}$}} & .49 & - & & & \\
\hline & & & & & & \\
\hline \multicolumn{2}{|l|}{ Digital content-creation } & .43 & .43 & - & & \\
\hline \multicolumn{2}{|l|}{ Safety } & .40 & .42 & .46 & - & \\
\hline \multirow[t]{5}{*}{ Problem solving } & & .37 & .44 & .49 & .44 & - \\
\hline & $M d$ & .08 & .11 & -.03 & -.02 & -.05 \\
\hline & $S D$ & .52 & .76 & .99 & 1.12 & .76 \\
\hline & Min & .08 & .81 & 3.01 & 2.68 & 1.25 \\
\hline & $\operatorname{Max}$ & -1.73 & -1.62 & -1.42 & -2.13 & -1.04 \\
\hline
\end{tabular}

\section{Latent profile analyses}

Table 4 shows the results of the LPA. The AIC, BIC and SSaBIC decreased from solutions 1 to 5 . This means that more profiles are a better solution. The Bootstrap-Likelihood-Ratio-Difference-Test indicates that more than four profiles are optimal too, because in all tests the hypothesis is rejected $(p<.001)$. Furthermore, a gradual heterogenization of the profiles is shown. This can be seen in the fact that groups with less than $10 \%$ of the respondents are represented in the four profiles. The entropy had the best value of 1.00 for the four-profile solution. However, the value was only slightly above the other three profiles. Furthermore, we evaluated the results with a leave-one-out cross-validation by discriminant analysis. The results in table 4 in the final column show that in profile four all cases are correctly classified (100\%). 
How student characteristics affect cooperative students' digital competences

Table 4. Indices and coefficients for solutions from profile 1 to 5.

\begin{tabular}{cccccccccc}
\hline $\begin{array}{c}\text { Pro- } \\
\text { file }\end{array}$ & AIC & BIC & $\begin{array}{c}\text { ssa- } \\
\text { BIC }\end{array}$ & $\begin{array}{c}p \\
B L R T\end{array}$ & $<5 \%$ & $<\mathbf{1 0 \%}$ & $<\mathbf{2 0 \%}$ & Entropy & $\begin{array}{c}\% \text { correct } \\
\text { classifica- } \\
\text { tion cases }\end{array}$ \\
\hline 1 & 4962 & 5002 & 4971 & & & & & & \\
2 & 4383 & 4448 & 4397 & $<.001$ & 0 & 0 & 1 & 0.96 & $97.10 \%$ \\
3 & 3999 & 4088 & 4018 & $<.001$ & 0 & 0 & 2 & 0.98 & $98.30 \%$ \\
4 & 3664 & 3777 & 3688 & $<.001$ & 0 & 1 & 2 & 1 & $100.00 \%$ \\
5 & 3371 & 3508 & 3400 & $<.001$ & 1 & 2 & 3 & 0.99 & $99.80 \%$ \\
\hline
\end{tabular}

Note: $A I C=$ Akaike's Information Criterion; $B I C=$ Bayesian Information Criterion; $s s a B I C=$ Sample size adjusted BIC; $p$ BLRT = $p$-value of Bootstrap-Likelihood-Ratio-Difference-Test. Column of $<5 \%,<10 \%$ and $<20 \%$ show, to what extent the profiles have lower than $5 \%, 10 \%$ or $20 \%$ of the sample. The column '\% correct classification cases' shows the results of the correct classification cases in \% based on the leave-one-out method for cross-validation.

In summary, the results suggest that a solution with four profiles is optimal. This is based on the result of the entropy and on the cross validation. However, theory-based criteria and reflection are needed to interpret the optimal number of profiles. After discussion with the research group, four profiles were selected.

\section{Interpreting the profiles}

Figure 4 shows that with just $7.5 \%$ of the participants, the first profile (profile one) had the lowest value medians of all four profiles. Problem solving is the only digital competence in this profile to show a competence value similar to that of the other three profiles. This is an interesting observation, which we were not sure how to interpret. However, we concluded that this group has an overall weak level of development with respect to digital competence. Hence, we referred to those in this group as reserved digitised.

While the profile with $10.9 \%$ of the participants (profile two) has slightly higher values than the reserved digitised, they are nonetheless lower than those for the other two profiles. Although the individuals in this group appear to have adapted to digitalisation, the values seem to indicate a lack of digital ability. Based on these findings, we named the second profile reserved appreciative.

The profile with nearly one quarter (23.2\%) of the participants (profile three) has higher values than the reserved digitised and the reserved appreciative. However, there is a pattern similarity between this group and the last group, with $58.4 \%$ of the sample (profile four). The digital competence domains problem solving and digital content creation have a similar median for profiles three and four with $M d=.23$ and $M d=.26$, respectively. This is the highest valued competence for profile three. Figure 4 shows that profile four has higher medians in the digital 
competences of information and data literacy $(M d=.08)$, safety $(M d=.23)$ and communication and collaboration $(M d=.14)$. Security and knowledge about information seem to be a central characteristic of profile four. Therefore, group three was labelled as advanced digitised and profile four as reflective digitised.

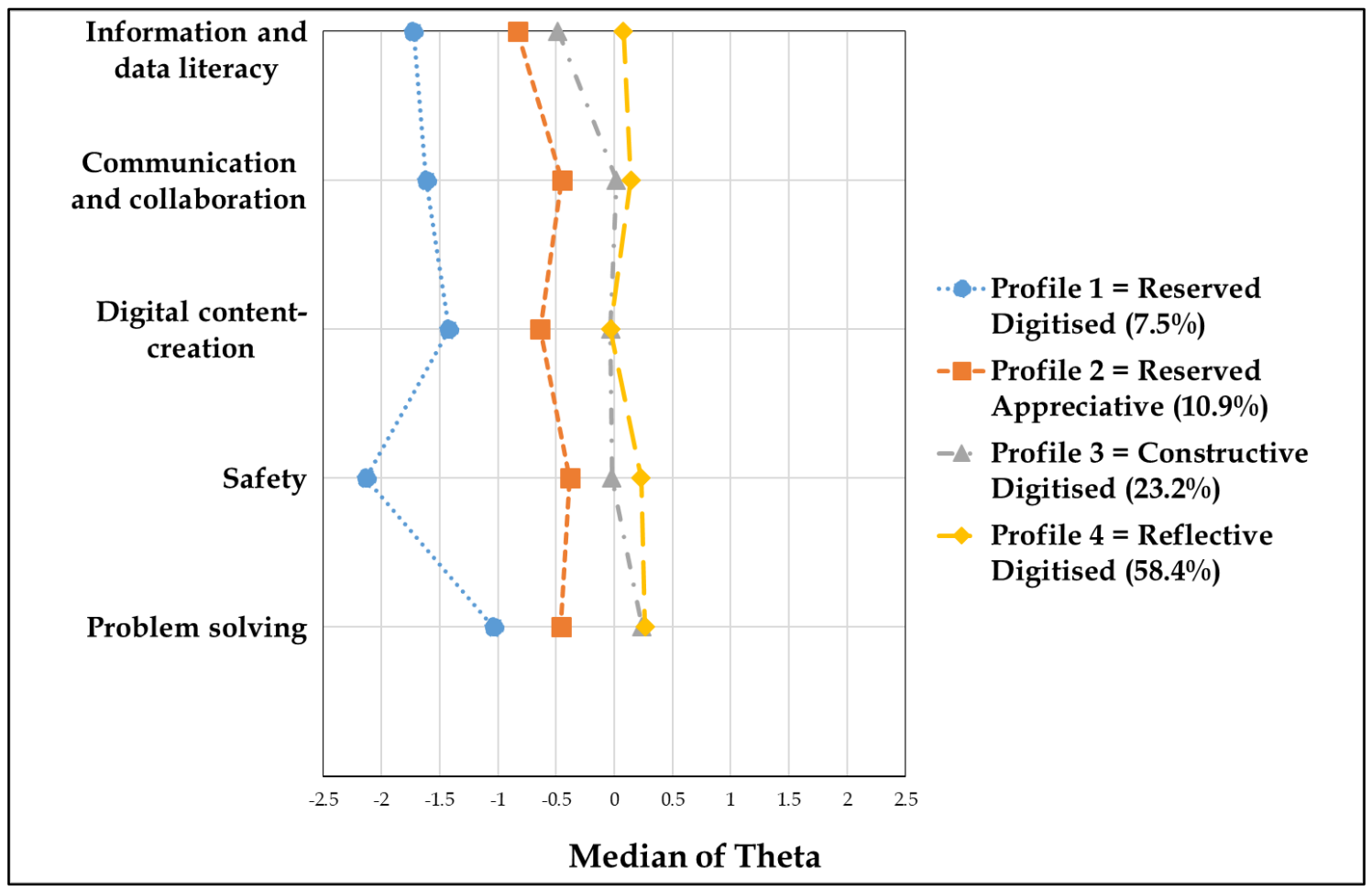

Figure 4. Graphic representation of the four competence profiles found among the 413 participants ('not very competent' (-2.5) to 'very competent' (2.5)).

After analysing the data for characteristic competence profiles, we wanted to know which of the assessed student characteristics can be associated with each of the profiles. To prove this assumption, we conducted an explorative analysis and calculated the correlation between profiles and demographics. Consequently, $x^{2}$-Tests including the four profiles and the demographic variables 'vocational apprenticeship' $\left(\chi^{2}(3,408)=5.03, p=.17\right)$, 'university entrance qualification' $\left(\chi^{2}(3,410)=4.17, p=.24\right)$, 'parent with an academic background' $\left(\chi^{2}(3,408)=1.80, p=\right.$ $.62)$, 'year of graduation from school' $\left(\chi^{2}(6,410)=7.98, p=.24\right)$, 'academic major' $\left(\chi^{2}(3,413)=.18, p=.98\right)$ and 'gender' $\left(\chi^{2}(3,401)=3.80, p=.28\right)$ were analysed. There are no significant differences. Tests undertaken by Analysis of Variance (ANOVA) for age $\left(F_{(3,399)}=.85, p=.47\right)$ and social background $\left(F_{(3,389)}=.60, p=\right.$ $.61)$ are also not significant. Figure 5 shows the distribution of the demographic characteristics for each of the four competence profiles. 
How student characteristics affect cooperative students' digital competences

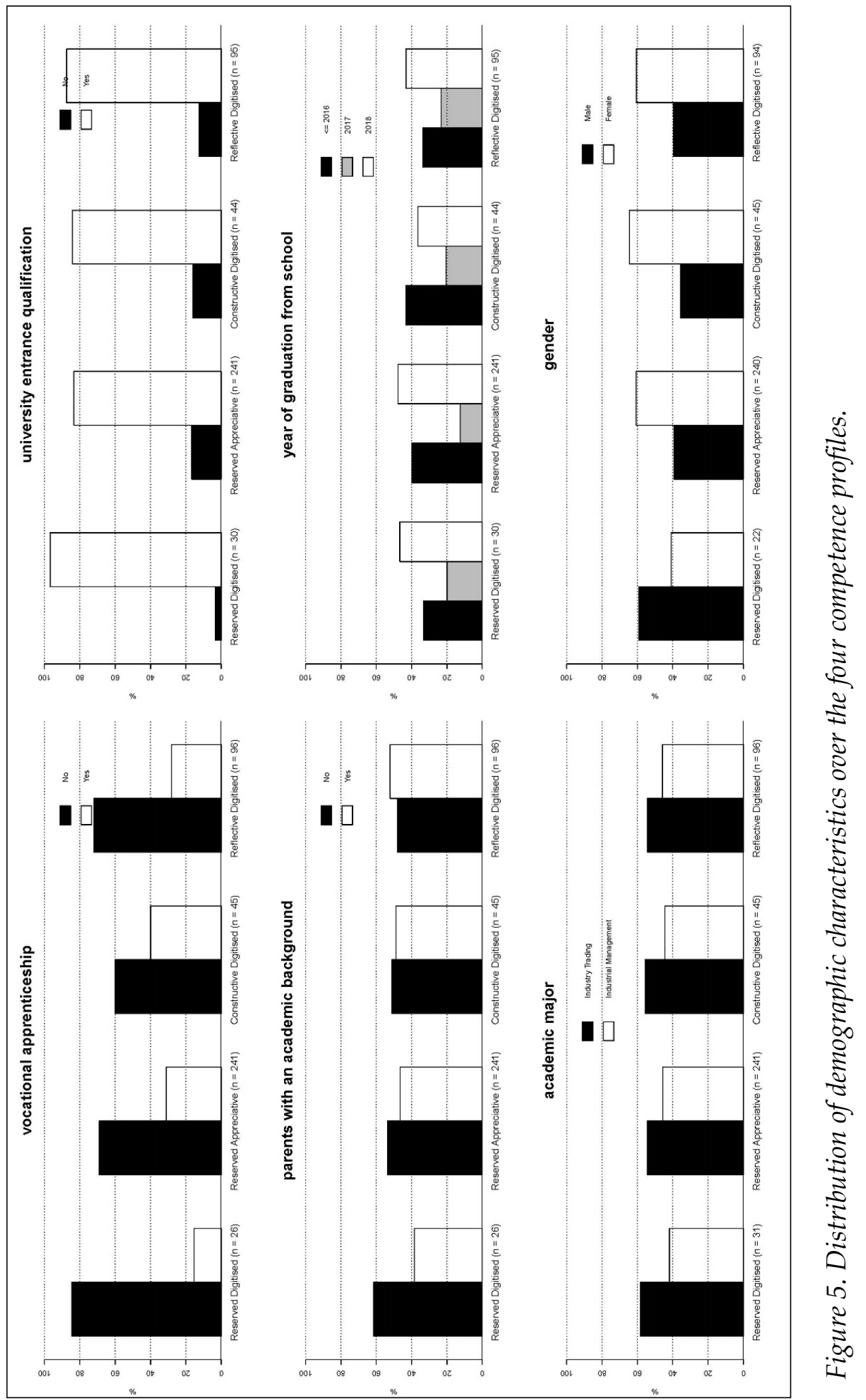




\section{Discussion and implications of the study}

As discussed above, we identified four digital competence profiles among the study participants: (1) reserved digitised, (2) reserved appreciative, (3) constructive digitised, and (4) reflective digitised. Reserved digitised students had the lowest competence score. While we could successfully demonstrate that students possess different degrees of digital competence, no correlations between demographic traits and the level of digital competence were found in the data. In other words, in this study neither personal nor structural (digital divide) student characteristics are predictors for the expression of digital competences. We cannot deduce from our results that the reflective digitised have the highest school marks, we cannot deduce that the difference between a reflective and a constructive digitised student is the academic background of their parents. We cannot deduce that the students with only few digital competences were also bad in school. This is an interesting finding, because the theory of the digital divide suggests that two structural factors - socio-economic background and gender - influence the expression of digital skills. It would be interesting to know if this pattern reproduces among vocational students in the Nordic Countries.

Our analysis showed that $80 \%$ of the students in the CSP consider themselves to be middle class, but less than half of the students have a parent with a university degree. This self-perception seems to accord with Weich's et al. (2017) finding that cooperative students are highly self-confident. These findings can be compared to another publication in this field, which found that cooperative students, despite their lower socio-economic background, have better university entrance scores than traditional university students (Kramer et al., 2011). According to the digital divide, a lower socio-economic status is followed by a lower level of digital competence and men outperform women. According to this theory and the demographic data we have of our students, we could not have expected $80 \%$ of our sample participants to score above average. We tentatively suggest that, with respect to digital competences, the potentially negative influence of coming from a low socio-economic background is compensated for by motivation, self-confidence, and advanced abilities (Kupfer, 2013) as well as a good university entrance examination score. Our study could not reproduce the other prediction of the digital divide, that is, that female participants would score significantly lower than their male counterparts. This was not the case. It might be noteworthy that another recent study examining prospective science teachers' and prospective engineers' digital competences suggests the opposite. Here socio-economic background and gender influenced the expression of digital competences (Schulze Heuling, Wild \& Vest, submitted).

From our study, we conclude that another factor (one not addressed in this study) might be more influential on the expression of digital competences for our sample than socio-economic background or gender: the impact of implicit 
learning. Previous studies found that common computer tasks, such as carrying out web searches or doing simple programming tasks, have a high impact on implicitly developing digital competences (Boechler, 2008; Greene et al., 2014; Mancy, 2007).

Overall, if demographic traits are less an indicator for the development of digital skills among CSP students, we still have to identify which factors such as implicit learning influence the development of advanced digital competences in order to effectively promote the acquisition of both general and, in particular, specific, profession-related, digital skills and competences. This is particularly important to find effective starting points for supporting those $20 \%$ of CSP students with less developed digital competences. Such an analysis is also relevant for the Nordic Countries and a task for future, collaborative research.

Furthermore, if implicit learning is an important factor for acquiring high digital competences, the implication for companies is that their commitment should embrace not only investing in technical equipment and the automation of digital processes, but also ICT education for their trainees and employees. The reserved digitised and reserved appreciative, which make up nearly $20 \%$ of the sample in our study, might profit from workplace-related implicit learning opportunities. It is they who must be especially prepared for the challenges of a digitised working world.

Beyond that, these study results are not only relevant to the very specific group of cooperative students. They are also of interest for VET in Germany and European countries for several reasons. Firstly, CSP and VET in Germany and other European countries all make use of similar structures in vocational education and training. Within cooperative education, the vocational training demands are similar to those of a classical, three-year vocational training programme leading to a journeymen certificate. For example, all students must accomplish the same tasks, such as passing exams related to specific professional skills and adapting and integrating the generalised vocation-related subject matter from school / university to the specific situation of the workplace in the training company. Furthermore, both groups must deliver certain goods, such as work samples or a journeyman's piece. Secondly, the educational systems to be found in European countries, particularly the Nordic countries, have much in common with the German three-year dual vet education system, in which three years of combined vocational school and vocational workplace training with a ratio of 2:3 (2/5 spent at the VET school and 3/5 spent at the workplace) typically leads to a journeyman certificate. We thus assume that similar findings could be made among VET students in Europe. It would be interesting to know if a reproduction study with VET students from Nordic Countries would deliver comparable results since these countries are considered as highly digitally developed.

Generally, the literature study and our study results show that more research on digital competences in VET needs to be done. For example, we need more 
studies on the formation of digital skills in VET and the influence of implicit learning on the expression of digital competences. Secondly, we need to know more about the factors that influence the development of digital skills, particularly for those with less developed digital competences. Thirdly, it might be useful to re-evaluate current study programmes in terms of how they support the development of digital competences. More insight into the extent to which digital competences are a prerequisite to VET, how they are assessed at the start of an apprenticeship and accordingly promoted thereafter, is also vital. Continuous assessment is needed to ensure that digital competences are adaptively taught during a person's studies. For applicants and graduates in VET or CSP, ongoing industrial training in digital competences can bind high-performing applicants or graduates to companies.

More country-specific research can help shed light on local patterns, thereby enabling more precise follow-up action. Such comparative studies are technically not difficult to conduct and could be compared to the results of this study, because we used a German version of the DigComp, the well-established European framework for assessing digital competences, which is, for example, also available in English.

The present study has limitations. Firstly, only students from a single university were interviewed. Secondly, we surveyed a very specific group, namely firstyear students in a business-focussed CSP. Thus, it is difficult to generalise from these results. Furthermore, the fact that students were recruited by their partner companies based on individual criteria could have influenced the results (Kupfer, 2013). The data was obtained through self-reported answers which could have caused response bias.

\section{Notes on contributors}

Lydia Schulze Heuling is Professor at the Department of Sport, Food and Natural Sciences at Western Norway University of Applied Science, Bergen, Norway. Lydia's fields of research are, among others, higher education and STEAM education research and practices.

Steffen Wild is Senior Postdoc at Heidelberg School of Education, Heidelberg University, and Privatdozent at Ludwigsburg University of Education, both Germany. Steffen is specialised in empirical educational research with focus on higher education and (quantitative) methods in social research. 
How student characteristics affect cooperative students' digital competences

\section{References}

Baas, M., \& Baethge, M. (2017). Entwicklung der Berufsausbildung in Klein- und Mittelbetrieben. Bertelsmann.

Bacher, J., \& Vermunt, J. K. (2010). Analyse latenter Klassen. In C. Wolf, \& H. Best (Eds.), Handbuch der sozialwissenschaftlichen Datenanalyse (pp. 553-574). Springer.

Balsmeier, B., \& Woerter, M. (2019). Is this time different? How digitalization influences job creation and destruction. Research Policy, 48(8).

Birnbaum, A. (1968). Some latent trait models and their use in inferring an examinee's ability. In F. Lord, \& M. Novick (Eds.), Statistical theories of mental test scores (pp. 397-479). Addison-Wesley.

Boechler, P., Leenaars, L., \& Levner, I. (2008). Recreational vs. educational computer experience: Predicting explicit and implicit learning outcomes during a website search. In K. McFerrin, R. Weber, R. Carlsen, \& D. Willis (Eds.), Proceedings of SITE 2008--Society for Information Technology E Teacher Education International Conference (pp. 2499-2501). Association for the Advancement of Computing in Education (AACE).

Braunstein, L. A., Takei, H., Wang F., \& Loken, M. K. (2011). Benefits of cooperative and work-integrated education for employers. In R. K. Coll, \& K. E. Zegwaard (Eds.), International handbook for cooperative and work-integrated education: International perspectives of theory, research and practice ( $2^{\text {nd }}$ ed., pp. 277-286). World Association for Cooperative Education.

Browne, M. W. (2000). Cross-validation methods. Journal of Mathematical Psychology, 44(1), 108-132.

Brynjolfsson, E., \& McAfee, A. (2017). Machine, platform, crowd: Harnessing our digital future. Norton \& Company.

Burchert, J., \& Schulte, S. (2014). Die Nutzung des Internets in der dualen Ausbildung: Eine berufspädagogische Betrachtung auf Basis empirischer Forschungsergebnisse. Peter Lang.

Canchu L., \& Louisa, H. (2009). Subcultures and use of communication information technology in higher education institutions. Journal Higher Education, 80(5), 564-590.

Castells, M. (2001). The internet galaxy: Reflections on internet, business, and society. Oxford University Press.

Coll, R., \& Zegwaard, K. E. (2011). International handbook for cooperative and workintegrated education: International perspectives of theory, research and practice $\left(2^{\text {nd }}\right.$ ed.). World Association for Cooperative Education (WACE).

Cooper, J. (2006). The digital divide: The special case of gender. Journal of Computer Assisted Learning, 22(5), 320-334.

Davaki, K. (2018). The underlying causes of the digital gender gap and possible solutions for enhanced digital inclusion of women and girls: Study for the European 
Parliament's Committee on Women's Rights and Gender Equality. Retrieved September 22, 2020, from https:/ / www.europarl.europa.eu/RegData/etudes/STUD/2018/604940/IP OL_STU(2018)604940_EN.pdf

De Witt, C. (2012). Neue Lernformen für die berufliche Bildung: Mobile learning - Social learning - Game based learning. Zeitschrift des Bundesinstituts für Berufsbildung, 41(3), 6-9.

DiMaggio, P., Hargittai, E., Neuman, W. R., \& Robinson, J. P. (2001). Social implications of the internet. Annual Review of Sociology, 27(1), 307-336.

Federal Institute for Vocational Education and Training. (2018). Datenreport zum Berufsbildungsbericht 2018: Informationen und Analysen zur Entwicklung der beruflichen Bildung. Federal Institute for Vocational Education and Training.

Federal Ministry of Education and Research. (2018). Berufsbildungsbericht 2018. Federal Ministry of Education and Research.

Ferrari, A. (2013). DigComp: A framework for developing and understanding digital competence in Europe. In Y. Punie, \& B. N. Brecko (Eds.), JRC scientific and policy reports (pp. 4-45). Publications Office of the European Union.

Geiser, C. (2010). Datenanalyse mit Mplus. Springer.

Goldhammer, F., Gniewosy, G., \& Zylka, J. (2006). ICT engagement in learning environments. In S. Kuger, E. Klieme, N. Jude, \& D. Kaplan (Eds.), Assessing Contexts of Learning (pp. 331-351). Springer.

Gollwitzer, M. (2012). Latent-class-analysis. In H. Moosbrugger, \& A. Kelava (Eds.), Testtheorie und Fragebogenkonstruktion (2nd ed., pp. 553-574). Springer.

Graf, L. (2013). The hybridization of vocational training and higher education in Austria, Germany, and Switzerland. Budrich UniPress Ltd.

Graf, L., Powell, J. J. W., Fortwengel, J., Bernhard, N., \& Deutscher Akademischer Austauschdienst. (2014). Dual study programmemes in global context: Internationalisation in Germany and transfer to Brazil, France, Qatar, Mexico and the US. DAAD.

Greene, J. A., Seung, B. Y., \& Copeland, D. Z. (2014). Measuring critical components of digital literacy and their relationships with learning. Computers $\mathcal{E}$ Education, 76, 55-69.

Hatlevik, O., Ottestad, G., \& Throndsen, I. (2015). Predictors of digital competence in 7th grade: A multilevel analysis. Journal of Computer Assisted Learning Archive, 31(3), 220-231.

Hatlevik, I. K. R., \& Hatlevik, O. E. (2018). Examining the relationship between teachers' ICT self-efficacy for educational purposes, collegial collaboration, lack of facilitation and the use of ICT in teaching practice. Frontiers in Psychology, 9, Article 935.

Haukås, M., \& Skjervheim, K. (2018). Vocational education and training in Europe: Norway. Cedefop ReferNet VET in Europe reports. Retrieved December 2, 2020, from 
http:/ /libserver.cedefop.europa.eu/vetelib/2019/Vocational_Education_Tra ining_Europe_Norway_2018_Cedefop_ReferNet.pdf

Hofmann, S., Hemkes, B., Joyce, S. L., König, M., \& Kutzner, P. (2019). AusbildungPlus in Zahlen: Duales Studium 2019. Trends und Analysen. Bundesinstitut für Berufsbildung.

Hu, Y., Gong, Y., Lai, C., \& Leung, F. K. S. (2018). The relationship between ICT and student literacy in mathematics, reading, and science across 44 countries: A multilevel analysis. Computers $\mathcal{E}$ Education, 125, 1-13.

Kaarakainen, M. T., Kivinen, A., \& Kaarakainen, S. S. (2017). Differences between the genders in ICT skills for Finnish upper comprehensive school students: Does gender matter? International Journal of Media, Technology and Lifelong Learning, 13(2), 1-16.

Kämäräinen, P., Gerrard, A., \& Müller, W. (2019). Strategies and training models for promoting digital competences in the field of vocational education and training: Reflections on policies, conceptual frameworks and innovation projects. In B. E. Stalder, \& C. Nägele (Eds.), Trends in vocational education and training research, Vol. II: Proceedings of the European Conference on Educational Research (ECER), Vocational Education and Training Network (VETNET) (pp. 179197). VETNET.

Kramer, J., Nagy, G., Trautwein, U., Lüdtke, O., Jonkmann, K., Maaz, K., \& Treptow, R. (2011). High class students in the universities, the rest in the other institutions of higher education: How students of different college types differ. Zeitschrift für Erziehungswissenschaft, 14, 465-487.

Künsting, J., Billich-Knapp, M., \& Lipowsky, F. (2012). Profile der Anforderungsbewältigung $\mathrm{zu}$ Beginn des Lehramtsstudiums. Journal for Educational Research Online, 4(2), 84-119.

Kupfer, F. (2013). Duale Studiengänge aus Sicht der Betriebe: Praxisnahes Erfolgsmodell durch Bestenauslese. Berufsbildung in Wissenschaft und Praxis BWP , 47(4), 25-29.

Kurz, C., \& Rieger, F. (2013). Arbeitsfrei: Eine Entdeckungsreise zu den Maschinen, die uns ersetzen. Riemann.

Lucas, R. E., \& Baird, B. M. (2006). Global self-assessment. In M. Eid, \& E. Diener (Eds.), Handbook of multimethod measurement in psychology (pp. 29-42). American Psychological Association.

Mc Cullough, C., Smirli, E., Ward, T., Harrison, T., \& Massy, J. (2002). eLearning und Ausbildung in Europa: Umfrage zum Einsatz von eLearning zur beruflichen Aus- und Weiterbildung in der Europäischen Union. Cedefop.

Mancy, R. (2007). Implicit learning and computer programming [Dissertation]. University of Glasgow.

Müller, L.-S., Stecher, B., Dathe, R., Boberach, M., Exel, S., \& Baethge, C. B. (2018). D21 Digitalindex 2017/2018: Jährliches Lagebild zur digitalen Gesellschaft. Retrieved May 1, 2019, from 
https:/ /initiatived21.de/app/uploads/2018/01/d21-digitalindex_2017_2018.pdf

Muthén, L. K., \& Muthén, B. O. (2010). Mplus version user guide. Retrieved September 2, 2019, from

https://www.statmodel.com/download/usersguide/Mplus\%20Users\%20G uide\%20v6.pdf

Murray, M. C., \& Pérez, J. (2014). Unraveling the digital literacy paradox: How higher education fails at the fourth literacy. Issues in Informing Science and Information Technology, 11, 85-100.

Pastor, D. A., Barron, K. E., Miller, B. J., \& Davis, S. L. (2007). A latent profile analysis of college students' achievement goal orientation. Contemporary Educational Psychology, 32(1), 8-47.

Ragnedda, M., \& Muschert, G. (2018). Theorizing digital divide. Routledge.

Reinhard, K., \& Pogrzeba, A. (2016). Comparative cooperative education: Evaluating Thai models on work-integrated learning, using the German Duale Hochschule Baden-Wuerttemberg model as a benchmark. Asia-Pacific Journal of Cooperative Education, 17(3), 227-247.

Reinhard, K., Pogrzeba, A., Townsend, R., \& Pop, A. P. (2016). A comparative study of cooperative education and work integrated learning in Germany, South Africa, and Namibia. Asia-Pacific Journal of Cooperative Education, 17(3), 249-263.

Rowsell, J., Morrell, E., \& Alvermann, D. E. (2017). Confronting the digital divide: Debunking brave new world discourses. The Reading Teacher, 71(2), 157-165.

Scherer, R., \& Siddiq, F. (2019). The relation between students' socioeconomic status and ICT literacy: Findings from a meta-analysis. Computers $\mathcal{E}$ Education, $138,49-58$.

Schulze Heuling, L. (2017). Does intra-institutional communication work? How educational players can provide a tailored environment for their vocational apprentices: An interview study. Unpublished data.

Schulze Heuling, L. (2018). Cross-border experiences in ICT-related vocational education between Denmark and Germany: An interview study. Unpublished data.

Schulze Heuling, L., Wild, S., \& Vest, A. (submitted). Digital competences of prospective science teachers and engineers: A latent profile and correspondence analysis.

Seeber, S., \& Seifried, J. (2019). Challenges and development prospects for vocational education and training in times of changing socioeconomic and technological conditions. Zeitschrift für Erziehungswissenschaft, 22, 485-508.

Senkbeil, M., Ihme, J. M., \& Schöber, C. (2019). Are first-semester and advanced university students ready for life and work in the digital world? Results of a standard setting method to describe ICT-related proficiency levels. Zeitschrift für Erziehungswissenschaft, 22(6), 1359-1384. 
Siddiq, F., \& Scherer, R. (2019). Is there a gender gap? A meta-analysis of the gender differences in students' ICT literacy. Educational Research Review, 27, 205-217.

Siddiq, F., Hatlevik, O. E., Olsen, R. V., Throndsen, I., \& Scherer, R. (2016). Taking a future perspective by learning from the past: A systematic review of assessment instruments that aim to measure primary and secondary school students' ICT literacy. Educational Research Review, 19, 58-84.

Skryabin, M., Zhang, J., Liu, L., \& Zhang, D. (2015). How the ICT development level and usage influence student achievement in reading, mathematics, and science. Computers $\mathcal{E}$ Education, 85, 49-58.

Smith, J. K., Given, L. M., Julien, H., Ouellette, D., \& DeLong, K. (2013). Information literacy proficiency: Assessing the gap in high school students' readiness for undergraduate academic work. Library $\mathcal{E}$ Information Science Research, 35(2), 88-96.

Statistisches Landesamt Baden-Württemberg. (2016). Ergebnisse der Absolventenbefragung 2013 an der Dualen Hochschule in Baden-Württemberg: Absolventinnen und Absolventen der Prüfungsjahre 2008 und 2011. Statistisches Landesamt Baden-Württemberg.

Survey of Schools: ICT in Education. (2012). Country profile Sweden. Retrieved March 24, 2020, from

https:/ /ec.europa.eu/information_society/newsroom/image/document/20 18-3/sweden_country_profile_30141CE0-E643-5AC4-

511FC13CBA34A32C_49456.pdf

Tabachnick, B., \& Fidell, L. F. (2013). Using mulitvariate statistics (6 $6^{\text {th }}$ ed.). Pearson.

Tadesse T, Gillies R. M., \& Campbell, C. (2018). Assessing the dimensionality and educational impacts of integrated ICT literacy in the higher education context. Australian Journal for Educational Technology, 34(1), 88-101.

Undervisningsministeriet. (2019). Idekatalog fra eud/eux-elevpanelet [Suggestions from the euc/eux-student panel]. Retrieved December 2, 2020, from https:/ / www.uvm.dk/-/media/filer/uvm/aktuelt/pdf-19/190227idekatalog-fra-eud-eux-elevpanel.pdf

Weich, M., Kramer, J., Nagengast, B., \& Trautwein, U. (2017). Beginning university: Dual or conventional? Differences in study entry requirements for beginning undergraduates in dual and non-dual study programmes at Bavarian universities of applied sciences. Zeitschrift für Erziehungswissenschaft, 20, 305-332.

Wild, S., \& Neef, C. (2019). The role of academic major and academic year for selfdetermined motivation in cooperative education. Industry and Higher Education, 33(5), 327-339.

Wild, S., \& Schulze Heuling, L. (2020a, online first). Student dropout and retention: An event history analysis among students in cooperative higher education. International Journal of Educational Research, 104. 
Wild, S., \& Schulze Heuling, L. (2020b). How do the digital competences of students in vocational schools differ from those of students in cooperative higher education institutions in Germany? Empirical Research in Vocational Education and Training, 12(5), 1-18.

Wild, S., \& Schulze Heuling, L. (2021). Re-evaluation of the D21-Digital-Index assessment instrument for measuring higher-level digital competences. Studies in Educational Evaluation, accepted.

Witte, J. C., \& Mannon, S. E. (2010). The internet and social inequalities. Routledge. Wolter, A. (2016). Der Ort des dualen Studiums zwischen beruflicher und akademischer Bildung: Mythen und Realitäten. In U. Faßhauer, \& E. Severing (Eds.), Verzahnung beruflicher und akademische Bildung: Duale Studiengänge in Theorie und Praxis (pp. 39-60). Federal Institute for Vocational Education and Training. 